\title{
COINS FROM THRACIAN AND LOWER MOESIAN MINTS FROM THE VIMINACIUM NECROPOLIS OF PEĆINE
}

\begin{abstract}
During the extensive archaeological rescue excavations of the southern necropoles at Viminacium, at one of them, Pecine, 17 coins were found from provincial issues of Thracian mints, issued by eight mints, and two pieces from Moesia Inferior, originating from one mint. Out of a total of 19 pieces, 11 were found in graves, and the others in the layers of the necropolis.
\end{abstract}

\section{KEYWORDS: ROMAN PROVINCES COINAGE, THRACE, MOESIA INFERIOR (LOWER MOESIA), VIMINACIUM, PEĆINE, VIŠE GROBALJA.}

Due to the necessity of building the power plant Kostolac 2, extensive archaeological rescue excavations were carried out, starting in $1977^{1}$, in the area of southern necropoles. ${ }^{2}$ At the site of Pećine, three Roman necropoles were registered, the most recent one of them having been established in the middle of the 1st century, where burials of cremated and inhumed deceased individuals were practiced in parallel. At the same time, another necropolis was established at Pećine, where only cremated deceased individuals were buried,

1 This paper represents a result of working on the project: IRS - Viminacium, Roman city and military legionary camp - research of the material and non-material culture of inhabitants by using the modern technologies of remote detection, geophysics, GIS, digitalization and 3D visualization (no. 47018), funded by the Ministry of Education, Science and Technological Development of the Republic of Serbia (Vojvoda, Tapavički-Ilić).

2 Within this area, nine necropoles were identified, of which five belong to the Roman period: Više Grobalja, three necropoles on the site of Pećine, and Burdelj; $c f$. Зотовић 1986: 41, ref. 4; 54-55; Зотовић, Јордовић 1990: 2; Vojvoda, Mrđić 2015: 9, ref. 2. with the exception of a few inhumation burials, which were all children's graves. The change in burial ritual, which occurred approximately around the middle of the 3rd century, lead to the abandonment of these cemetery zones and the formation of new ones, in which inhumation became the only form of burial. At that time, the necropolis of Burdelj was established, as well as the third necropolis at Pećine, the former of which was in use up until approximately the middle of the 4th century, and the latter up until the middle of the 5th century (Vojvoda, Mrđić 2015: 9, ref. 3-4; Vojvoda, Mrđić 2017: 9, ref. 3).

During the already mentioned research at the necropoles at Pećine, a total of 3,865 coins were discovered. ${ }^{3}$ Out of this total, 3,497 pieces were available for examination (Vojvoda, Mrđić 2017: 10 , Table 1), ranging from 32/31 BC (Marcus An-

3 Coins were retrieved from graves and from layers of the necropolis (sacrifice surfaces formed above individual graves or groups of graves). 


\begin{tabular}{|c|c|c|c|c|c|c|}
\hline Province & Mint & $\begin{array}{l}\text { Mint: } \\
\text { pieces } \\
\text { in total }\end{array}$ & $\begin{array}{l}\text { Emperor or member } \\
\text { of imperial family }\end{array}$ & $\begin{array}{l}\text { Cat. } \\
\text { no. }\end{array}$ & Pieces & $\%$ \\
\hline \multirow[t]{14}{*}{ Thrace } & Serdica & & Lucius Verus & 1 & 1 & 5.26 \\
\hline & & 2 & Caracalla & 2 & 1 & 5.26 \\
\hline & Anchialus & & Hadrianus & 3 & 1 & 5.26 \\
\hline & & 2 & Gordian III & 4 & 1 & 5.26 \\
\hline & Pautalia & & Antoninus Pius & 5 & 1 & 5.26 \\
\hline & & & Faustina II & 6 & 1 & 5.26 \\
\hline & & 4 & Caracalla & $7-8$ & 2 & 10.53 \\
\hline & Deultum & 1 & Gordian III & 9 & 1 & 5.26 \\
\hline & Byzantium & 1 & unknown & 10 & 1 & 5.26 \\
\hline & Hadrianopolis & & Caracalla & $11-12$ & 2 & 10.53 \\
\hline & & 3 & Gordian III & 13 & 1 & 5.26 \\
\hline & Philippopolis & 2 & Antoninus Pius & $14-15$ & 2 & 10.53 \\
\hline & Perinthos & & Caracalla & 16 & 1 & 5.26 \\
\hline & & 2 & Severus Alexander & 17 & 1 & 5.26 \\
\hline \multirow[t]{2}{*}{ Moesia Inferior } & $\begin{array}{l}\text { Nicopolis ad } \\
\text { Istrum }\end{array}$ & & Caracalla & 18 & 1 & 5.26 \\
\hline & & 2 & Elagabalus & 19 & 1 & 5.26 \\
\hline Total & & 19 & & & 19 & 100 \\
\hline
\end{tabular}

Table 1 - Coins issued by Thracian and Lower Moesian mints at the necropolis of Pećine.

tonius) up to $423 \mathrm{AD}$ (Theodosius II).4 Imperial coinage is represented with $84.38 \%$ and provincial coinage with $15.58 \%$ (Vojvoda, Mrđić 2017: 10, Chart 1). By comparing the same results from the necropolis of Više Grobalja, we may perceive

4 An inventory of the entire numismatic material from the already mentioned rescue excavations was made in 2005 and 2006 at the National Museum of Požarevac (M. Vojvoda, D. Spasić-Đurić). It was noted that a certain number of specimens had either been lost or destroyed during the conservation process (367 pieces). A similar situation, found during the making of the inventory, was also noted with specimens from the necropolis of Više Grobalja - according to terrain documentation, 3,161 pieces were found, out of which 2,736 were preserved ( $c f$. Vojvoda, Mrđić 2015: 10, ref. 6). We would like to take this opportunity to thank our colleague Dragana Spasić-Đurić for kindly allowing us access to the material and for her involvement. a minor difference in percentages, which were, in the other case, $79.61 \%$ (imperial) and $20.30 \%$ (provincial) (Vojvoda, Mrđić 2015: 10, Table 1).

Out of the 545 pieces from the necropolis of Pećine that were identified as provincial coinage, a total of 19 pieces were registered $(3.50 \%)$ that were issued from the Thracian (17) and Lower Moesian (2) mints (Table 1). This represents a somewhat lower percentage compared to the neighbouring necropolis at Više Grobalja, where 25 pieces were registered, $4.50 \%$ of the total number of coins registered from provincial mints (Vojvoda 2011: 139-152; Vojvoda, Mrđić 2015: 1415, ref. 12). The difference in the representation of the mints from the two provinces is also notable at 
the necropoles of Više Grobalja and Pećine. Coins from Moesia Inferior mints were far more present at the necropolis of Više Grobalja than at the necropolis of Pećine (Graph 1a, b).

Through a comparative analysis of coin finds issued by mints from Thrace and Moesia Inferior at both necropoles at Viminacium, we can note similarities in several aspects: the presence of coinage of rulers and their family members belongs to approximately the same chronological range: Hadrian (Pećine) /Antoninus Pius (Više Grobalja) - Gordian III (Pećine) / Philip I (Više Grobalja) (Table 2; Vojvoda 2011: 140, Table 2); coins from Caracalla have the highest percentage (Pećine 36.84\%; Više Grobalja 20\%) and, finally, the most common are issues from the mint of Pautalia (Table 1; Vojvoda 2011: 139-140, Table 1).

\begin{tabular}{|c|c|c|}
\hline $\begin{array}{c}\text { Emperor or member of } \\
\text { imperial family }\end{array}$ & Pieces & $\%$ \\
\hline Hadrian & 1 & 5.26 \\
\hline Antoninus Pius & 3 & 15.80 \\
\hline Lucius Verus & 1 & 5.26 \\
\hline Faustina II & 1 & 5.26 \\
\hline Caracalla & 7 & 36.84 \\
\hline Elagabalus & 1 & 5.26 \\
\hline Severus Alexander & 1 & 5.26 \\
\hline Gordian III & 3 & 15.80 \\
\hline Unknown & 1 & 5.26 \\
\hline Total & 19 & 100 \\
\hline
\end{tabular}

Table 2 - Percentage distribution of coin specimens of certain rulers or their family members at the necropolis of Pećine.

Considering the noted similarities, and so as to obtain a better interpretation of these monetary findings, we believe that they should be considered as a whole, especially because of the circumstances regarding the documentation of findings from both necropoles during the research.5 Only after

5 Extensive and contemporary archaeological excavations

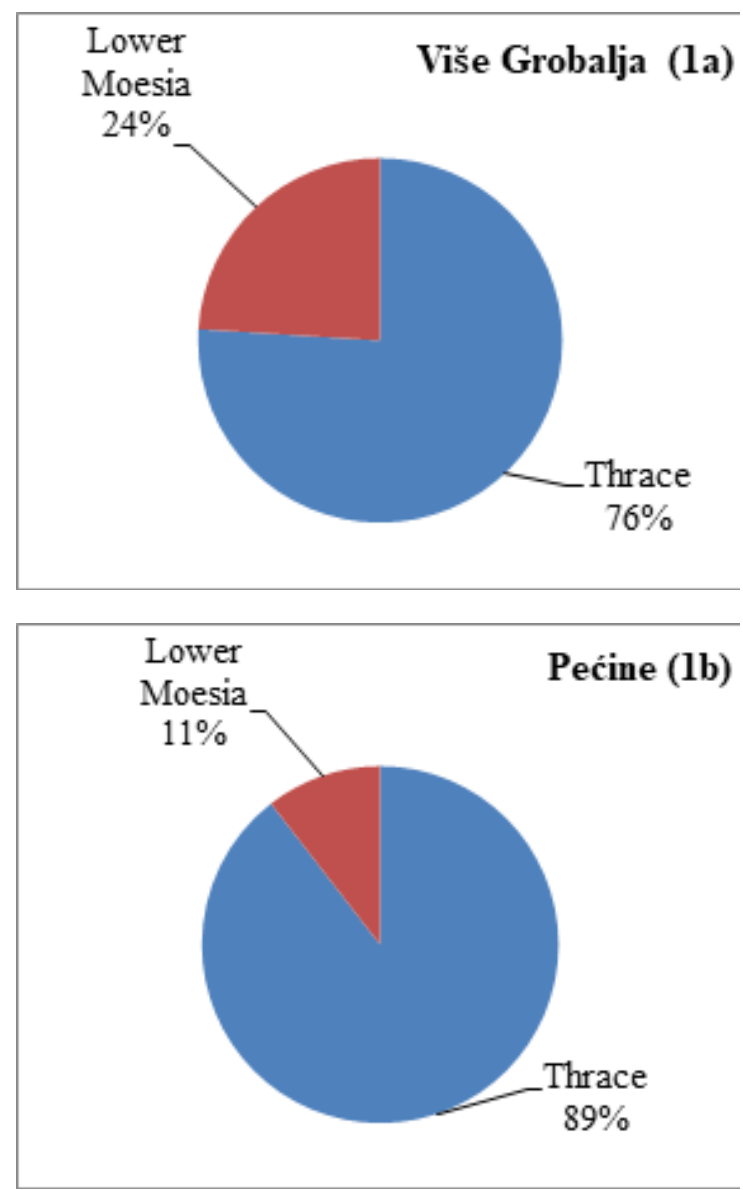

Graph 1a and $1 \mathrm{~b}$ - Representation of Thracian and Lower Moesian mints at the necropolis of Više Grobalja (1a) and the necropolis of Pećine (1b).

a detailed examination and publishing of all grave units and findings from both of the necropoles will it be possible to determine with any certainty the zones and chronological frames, though differenc-

at the adjoining sites of Više Grobalja and Pećine, naturally required that a system of documentation of findings be established as well, from the very beginning of the works. As already mentioned before (cf. supra ref. 2), during the research at Pećine, zones of three necropoles were discovered, the most recent of which was contemporary with the necropolis at the site of Više Grobalja and they probably represent one unit. Terrain documentation (excavation diaries, inventories of findings, grave numeration, etc.) had been made, from the start, separately for the two sites, and the three necropoles at Pećine were treated as a whole. The numismatic material, as well as other findings, is kept, even today, in thematic units, according to terrain inventories, which don't follow the zones of the three necropoles. The excavations were performed at the same time, and terrain inventory numbers were assigned daily on the basis of numerus currens (Vojvoda, Mrđić 2017: 14-15, ref. 16). 
es between them were noted during the research. For the time being, all indications point to the conclusion that the necropolis of Više Grobalja and the oldest burial zone at Pećine, in which cremations and inhumations were practiced at the same time, represented one necropolis at the time they were used. The question regarding a part of the cemetery zone at Pećine, in which there are graves with cremations and child inhumations only, with findings chronologically contemporary with the previous one, remains opened until a detailed analysis of all grave units is performed. It is possible that it was a part of the same necropolis, representing the burial zone of a population which practiced only cremation, but this remains to be confirmed by an anthropological analysis of the osteological material. The third area of burials at Pećine, consisting exclusively of inhumations, certainly represents a chronologically separate necropolis.

Hence, considered as a whole from the total number of coin specimens which were available for examination $(6,233), 61,100$ specimens belong to provincial minting, which represents $17.65 \%$. Coins from 16 provinces and 36 mints are present, mostly from Asia Minor and the Balkans. If we observe the presence of coins from certain provinces, Bithynia is by far the best represented, with $58.85 \%$, out of which the largest number came from the mint of Nicaea (55.82\%) compared to the total number of provincial mints issues present. It is followed by Upper Moesia (Moesia Superior) and the mint of Viminacium with $19.17 \%$, Macedonia with $13.59 \%$ and Thrace and Lower Moesia with 4.50\% (Borić-Brešković, Vojvoda 2017: 2, ref. 6).

The findings issued by the Thracian and Lower Moesian mints, originating from cemetery zones at the sites of Više Grobalja and Pećine, belong to the chronological range from Hadrianus to Philip I, with a total of 44 pieces (Table 3 ).

6 A total of 6,233 coins were available for examination (2,736 Više Grobalja; 3,497 Pećine). A certain number of pieces were either lost or destroyed during the conservation process (Vojvoda, Mrđić 2015: 10, ref. 6; Vojvoda, Mrđić 2017, 10-11, ref. 5).

\begin{tabular}{|c|c|c|}
\hline $\begin{array}{c}\text { Emperor or member } \\
\text { of imperial family }\end{array}$ & Pieces & $\%$ \\
\hline Hadrian & 1 & 2.27 \\
\hline Antoninus Pius & 5 & 11.36 \\
\hline Marcus Aurelius & 2 & 4.54 \\
\hline Lucius Verus & 1 & 2.27 \\
\hline Faustina II & 4 & 9.10 \\
\hline Commodus & 1 & 2.27 \\
\hline Septimius Severus & 4 & 9.10 \\
\hline Caracalla & 12 & 27.30 \\
\hline Plautilla & 1 & 2.27 \\
\hline Geta & 3 & 6.81 \\
\hline Elagabalus & 2 & 4.54 \\
\hline Severus Alexander & 1 & 2.27 \\
\hline Gordian III & 5 & 11.36 \\
\hline Philip I & 1 & 2.27 \\
\hline Unknown & 1 & 2.27 \\
\hline Total & 44 & 100 \\
\hline
\end{tabular}

Table 3 - Percentage distribution of coin specimens of certain rulers or their family members at the necropoles of Više Grobalja and Pećine together.

We may note an increased influx of coins from the Thracian and Lower Moesian mints at Viminacium from the time of the reign of Antoninus Pius, and the largest influx was noted during the reign of Caracalla (Graph 2). These calculations confirm the already noted lack of bronze coins of imperial coinage in the circulation of Upper Moesia during the reigns of the emperors from Antoninus Pius to Commodus. In this period, the highest presence was noted of provincial coinage from the Macedonian mints, most prominently Stoba, followed by the coins from mints in Asia Minor, Thrace and Lower Moesia. The situation changed during the Severian period, when a far lower presence of imperial issues of bronze coins can be noted as well as twice as many provincial coins compared to the previous period, with the largest number of specimens originating from the 


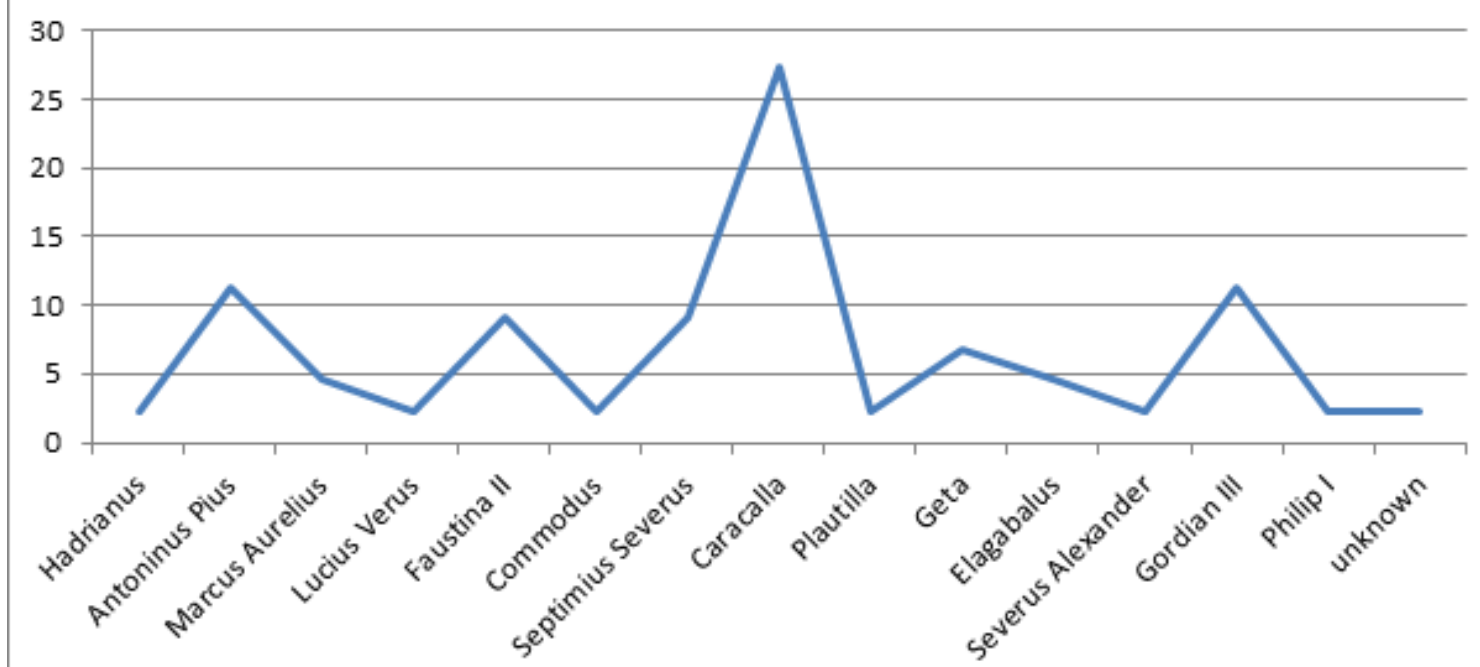

Graph 2 - Distribution of coins from Thracian and Lower Moesian mints at the necropoles of Više Grobalja and Pećine, according to rulers and their family members.

mint at Stoba. After this mint was closed during Caracalla's reign, a significant influx of money can be noted from the Bithynian mint in Nicaea, which culminated during the reign of Severus Alexander. A similar situation continued during the first years of the reign of Gordian III, until the establishment of the Viminacium mint. The beginning of circulation of coins from this mint influenced the influx of coinage from Gordian III from the mint at Nicaea. The analysis of Viminacium monetary findings showed that in the period from Philip I up to Valerian I and Gallienus almost all provincial issues came from the mint at Viminacium, while only three specimens were noted from the mint at Nicaea. It is interesting to note that at the time of the greatest influx of money from Nicaea during the reign of Severus Alexander, notable issues of autochthonous coins were being minted again in Macedonia (Koinon of the Macedonians), which usually had no significant share of the circulation in the territory of Moesia Superior at this time (Црнобрња 1981: 5-6; Војвода, Петровић 2011: 288-289; Војвода, Јесретић 2012: 121-122; Војвода 2013: 156-157; Vojvoda, Mrđić 2015: 14-16, ref. 10-13; Војвода, Бранковић 2016: 108-109; Vojvoda 2017: 135; Vojvoda, Mrđić 2017: 17, ref. 20-23; 58, ref. 105; Borić-Brešković, Vojvoda 2017: 9-10).
When it comes to the presence of coins from certain mints, Pautalia is dominant with $29.50 \%$, followed by Hadrianopolis (13.70), and Philippopolis and Perinthos (with $9.10 \%$ each), while others are present in a smaller percentage (Table 4).

\begin{tabular}{|c|c|c|c|}
\hline Province & Mint & Pieces & $\%$ \\
\hline Thrace & Pautalia & 13 & 29.50 \\
\hline & Hadrianopolis & 6 & 13.70 \\
\hline & Philippopolis & 4 & 9.10 \\
\hline & Perinthos & 4 & 9.10 \\
\hline & Anchialus & 2 & 4.54 \\
\hline & Serdica & 2 & 4.54 \\
\hline & Deultum & 1 & 2.27 \\
\hline & Byzantium & 1 & 2.27 \\
\hline & $\begin{array}{c}\text { Augusta } \\
\text { Traiana }\end{array}$ & 1 & 2.27 \\
\hline $\begin{array}{c}\text { Lower } \\
\text { Moesia }\end{array}$ & Mesembria & 1 & 2.27 \\
\hline & Plotinopolis & 1 & 2.27 \\
\hline Total & Marcianopolis & 1 & 2.27 \\
\hline
\end{tabular}

Table 4 - Percentage distribution of Thracian and Lower Moesian mints at the necropoles of Više Grobalja and Pećine together. 
Mints from Thrace and Moesia Inferior obviously provided a certain share of small bronze coins in Moesia Superior until the reign of Caracalla, along with the Macedonian mints, which still remained the dominant source. The exceptional appearance of coins from the Bithynian mint of Nicaea, in the money flow of Moesia Superior, during the reign of Severus Alexander, was

\section{CATALOGUE}

\section{Notes to the Catalogue}

The catalogue is arranged chronologically according to the reigns of the Roman emperors.

Catalogue contains the following data:

Column 1 - Catalogue number.

Column 2 - Obverse legend and description.

Column 3 - Reverse legend and description.

Column 4 - Weight (gr); Size (mm); Axis (sides of the World).

Column 5 - Denomination; $c f$. Abbreviations.

Column 6 - Position of find; $c f$. Abbreviations.

Column 7 - References.

Column 8 - Date

Column 9 - Inventory number $(\mathrm{C}$ - number $)$ and additional information (for example: broken, perforated, cmk., NP (not preserved), etc.).

\section{Reference / References:}

BMC Thrace - Catalogue of Greek Coins. The Tauric Chersonese, Sarmatia, Dacia, Moesia, Thrace.

WBR - W.H. Waddington, E. Babelon et Th. Reinach, Recueil général des Monnaies grècques d'Asie Mineure, Nicée et Nicomédie.

Мушмовъ - Н. А. Мушмовъ, Антични монети на Балкански полуостров.

Varbanov III - I. Varbanov, Greek Imperial Coins. Vol. III. Thrace.

RPC online - $\mathrm{http}: / / \mathrm{rpc}$.ashmus.ox.ac.uk/coins

SNGvA - Sylloge Nummorum Graecorum, Deutschland, Sammlung Hans Von Aulock.

SNG Cop - H. E. Mathiesen (ed.), Sylloge Num- certainly linked to the earlier provisions from the mint at Stoba and later provincial coinage at Viminacium. Monetary findings from Viminacium, with the large number of pieces and the reliable finding place, contribute largely to solving the questions regarding the boundaries of circulation of provincial coins in this part of the Empire.

morum Graecorum. Aarhus University, Denmark, Copenhagen 1986: Munksgaard.

SNG France - H. Nicolet, Sylloge Nummorum Graecorum, France. Collection Jean et Marie Delepierre.

SNG Slovenia III - P. Kos, A. Šemrov, Sylloge Nummorum Graecorum Slovenia.

\section{Abbreviations:}

$$
\begin{aligned}
& \text { Cmk. - countermark } \\
& \text { ex - exergue } \\
& \text { 1. - left } \\
& \text { r. - right } \\
& \text { stg. - standing } \\
& \text { std. - seating } \\
& \text { adv. - advancing } \\
& \text { hld. - holding } \\
& \text { laur. - laureate } \\
& \text { rad. - radiate } \\
& \text { cuir. - cuirassed } \\
& \text { dr. - draped } \\
& \text { diad. - diademed } \\
& \text { G - inhumations } \\
& \text { G1 - cremations }
\end{aligned}
$$

Trench etc. - mark of trench for specimens which have been found in a layer, outside the graves.

\section{Photos}

Chosen specimens are presented in photographic form and their numeration on the plates is coordinateed with the catalogue numbers. 


\section{THRACE}

\section{MINT OF SERDICA}

LUCIUS VERUS

\begin{tabular}{|c|c|c|c|c|c|c|c|}
\hline \multicolumn{8}{|c|}{$\mathbf{A E}$} \\
\hline Cat. & Obverse & Reverse & $\begin{array}{l}\text { Wt. } \\
\text { Size } \\
\text { Axis }\end{array}$ & $\begin{array}{l}\text { Position } \\
\text { of find. }\end{array}$ & Ref. & Date & Vim. Coll. \\
\hline 1 & $\begin{array}{c}{[\mathrm{AV}][\mathrm{KA}] \mathrm{I} \Lambda} \\
\text { AVPH- } \Lambda \mathrm{IO} \\
\text { OVHPOC } \\
\text { Head laur. r. }\end{array}$ & $\begin{array}{c}\text { CEP- } \Delta \Omega N \\
\text { Tyche wearing } \\
\text { mural-crown std. } \\
\text { 1., hld. sceptre } \\
\text { and cornucopiae. }\end{array}$ & $\begin{array}{c}9,49 \\
27,33 \\
S\end{array}$ & $G-818$ & $\begin{array}{c}\text { RPC online, } \\
\text { Vol. 4, no. } \\
7396 .^{7}\end{array}$ & $161-169$ & 2735 \\
\hline
\end{tabular}

CARACALLA

AE

\begin{tabular}{|c|c|c|c|c|c|c|c|}
\hline Cat. & Obverse & Reverse & $\begin{array}{l}\text { Wt. } \\
\text { Size } \\
\text { Axis }\end{array}$ & $\begin{array}{l}\text { Position } \\
\text { of find. }\end{array}$ & Ref. & Date & Vim. Coll \\
\hline 2 & $\begin{array}{c}\text { AVT [...] - } \\
\text { ANTONINOC } \\
\text { Bust dr., cuir., r., } \\
\text { head laur. }\end{array}$ & 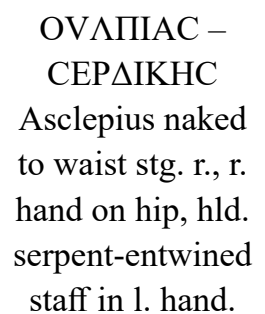 & $\begin{array}{c}16,82 \\
29,72 \\
\mathrm{NE}\end{array}$ & $G-443$ & $\begin{array}{l}\text { Мушмовъ } \\
\text { no. } 4818 .\end{array}$ & $211-217$ & 1923 \\
\hline
\end{tabular}

MINT OF ANCHIALUS

HADRIANUS

AE

\begin{tabular}{|c|c|c|c|c|c|c|c|}
\hline Cat. & Obverse & Reverse & $\begin{array}{l}\text { Wt. } \\
\text { Size } \\
\text { Axis }\end{array}$ & $\begin{array}{l}\text { Position } \\
\text { of find. }\end{array}$ & Ref. & Date & Vim. Coll. \\
\hline 3 & $\begin{array}{l}\text { Illegible. } \\
\text { Bust r., head laur. }\end{array}$ & $\begin{array}{c}\text { OV } \Lambda \Pi I A N \Omega N- \\
{[\mathrm{A} \Gamma \mathrm{XIA} \Lambda \mathrm{E} \Omega \mathrm{N}]} \\
\text { Fortuna stg. 1., } \\
\text { hld. rudder and } \\
\text { cornucopiae. }\end{array}$ & $\begin{array}{c}15.68 \\
28.64 \\
\mathrm{~N}\end{array}$ & $G-1859$ & $\begin{array}{c}\text { Мушмовъ } \\
/\end{array}$ & $117-138$ & $\begin{array}{c}5223 \\
\mathrm{NP}\end{array}$ \\
\hline
\end{tabular}

7 http://rpc.ashmus.ox.ac.uk/search/quick/?q=7396\&search 


\section{GORDIAN III}

\begin{tabular}{|c|c|c|c|c|c|c|c|}
\hline \multicolumn{8}{|c|}{$\mathbf{A E}$} \\
\hline Cat. & Obverse & Reverse & $\begin{array}{l}\text { Wt. } \\
\text { Size } \\
\text { Axis }\end{array}$ & $\begin{array}{l}\text { Position } \\
\text { of find. }\end{array}$ & Ref. & Date & Vim. Coll. \\
\hline 4 & $\begin{array}{c}\text { AVTK M ANT } \\
\text { ГOR } \triangle \text { IANO } \\
\text { AVГ CE (around) } \\
\text { ex - TPANKV } \\
\Lambda \text { IENA } \\
\text { Bust of } \\
\text { Gordianus III } \\
\text { dr. head laur, r. } \\
\text { facing bust of } \\
\text { Tranquilllina } \\
\text { dr., l. }\end{array}$ & $\begin{array}{c}\text { [OY] }] \Lambda \Pi I A N \Omega N \\
-[\mathrm{A} \Gamma \mathrm{X}] \\
\text { IA } \Lambda \mathrm{E} \Omega \mathrm{N} \\
\text { Nemesis stg. 1., } \\
\text { hld. scales and } \\
\text { cornucopiae; at } \\
\text { foot, wheel. }\end{array}$ & $\begin{array}{c}14,65 \\
31,66 \\
\mathrm{~S}\end{array}$ & $\begin{array}{l}\text { Nivela- } \\
\text { tion }\end{array}$ & $\begin{array}{c}\text { Мушмовъ } \\
2956\end{array}$ & $238-244$ & $\begin{array}{c}4945 \\
\mathrm{NP}\end{array}$ \\
\hline
\end{tabular}

MINT OF PAUTALIA

ANTONINUS PIUS

AE

\begin{tabular}{|c|c|c|c|c|c|c|c|}
\hline Cat. & Obverse & Reverse & $\begin{array}{l}\text { Wt. } \\
\text { Size } \\
\text { Axis }\end{array}$ & $\begin{array}{l}\text { Position } \\
\text { of find. }\end{array}$ & Ref. & Date & Vim. Coll. \\
\hline 5 & $\begin{array}{c}\text { AVT KAI T } \\
\text { AI A } \Delta \text { PI - } \\
\text { ANT } \Omega \text { NINOC } \\
\text { Bust dr. cuir. r., } \\
\text { head laur. }\end{array}$ & 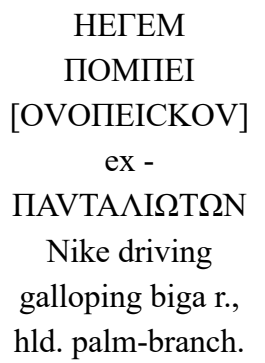 & $\begin{array}{c}17,38 \\
30,62 \\
\mathrm{~S}\end{array}$ & $\begin{array}{c}\text { Trench } \\
340\end{array}$ & $\begin{array}{c}\text { RPC } 4 \\
\text { online } \\
\text { no. } 8744 \\
\text { (temporary) }^{8}\end{array}$ & $138-161$ & $\begin{array}{c}8728 \\
\text { NP }\end{array}$ \\
\hline
\end{tabular}

FAUSTINA II

Striking under Marcus Aurelius

\begin{tabular}{|c|c|c|c|c|c|c|c|}
\hline \multicolumn{8}{|c|}{$\mathbf{A E}$} \\
\hline Cat. & Obverse & Reverse & $\begin{array}{l}\text { Wt. } \\
\text { Size } \\
\text { Axis }\end{array}$ & $\begin{array}{l}\text { Position } \\
\text { of find. }\end{array}$ & Ref. & Date & Vim. Coll. \\
\hline 6 & $\begin{array}{l}\text { FAVSTEINA - } \\
\text { CEBACTH } \\
\text { Bust dr. r., head } \\
\text { with band (?), } \\
\text { hair waved and } \\
\text { coiled on back of } \\
\text { head. }\end{array}$ & $\begin{array}{l}\text { OV } \Lambda \text { ПIAC - } \\
\text { ПAVTA } \Lambda \text { IAC } \\
\text { Hygeia stg. r., } \\
\text { feeding snake in } \\
\text { arms. }\end{array}$ & $\begin{array}{c}6,18 \\
2,94 \\
\text { NE }\end{array}$ & $\begin{array}{c}\text { Trench } \\
343\end{array}$ & $\begin{array}{c}\text { Мушмовъ } \\
4115 .\end{array}$ & $161-175$ & $\begin{array}{c}8973 \\
\text { NP }\end{array}$ \\
\hline
\end{tabular}

$\overline{8 \mathrm{http}: / / \text { rpc.ashmus.ox.ac.uk/search/quick/?q=8744\&search }}=$ 
CARACALLA

\begin{tabular}{|c|c|c|c|c|c|c|c|}
\hline \multicolumn{8}{|c|}{$\mathbf{A E}$} \\
\hline Cat. & Obverse & Reverse & $\begin{array}{l}\text { Wt. } \\
\text { Size } \\
\text { Axis }\end{array}$ & $\begin{array}{l}\text { Position } \\
\text { of find. }\end{array}$ & Ref. & Date & Vim. Coll. \\
\hline 7 & $\begin{array}{c}\text { AVT K M AVPH } \\
\text {-ANT } \Omega \text { NEINOC } \\
\text { Bust dr. cuir. r., } \\
\text { head laur. }\end{array}$ & $\begin{array}{l}\text { OVАПIАC - } \\
\text { ПАVТААIA } \\
\text { Homonoia stg. 1., } \\
\text { sacrificed on altar } \\
\text { from patera and } \\
\text { hld. cornucopiae. }\end{array}$ & $\begin{array}{c}19.78 \\
30.88 \\
\mathrm{~S}\end{array}$ & $\begin{array}{c}\text { Trench } \\
353\end{array}$ & $\begin{array}{c}\text { Мушмовь } \\
4247 .\end{array}$ & $198-217$ & $\begin{array}{c}9970 \\
\text { NP }\end{array}$ \\
\hline 8 & $\begin{array}{c}\text { AVT K M AVRH - } \\
\text { [ANT } \Omega \text { NEINOC] } \\
\text { Bust dr. r., head } \\
\text { laur. }\end{array}$ & $\begin{array}{l}\text { OYАПІАС - } \\
\text { ПАVТА IA } \\
\text { Woman stg. 1., } \\
\text { hld. patera. } 1 . \\
\text { hand beside the } \\
\text { body. }\end{array}$ & $\begin{array}{c}15,80 \\
29,98 \\
\mathrm{NE}\end{array}$ & $G-1915$ & $\begin{array}{c}\text { Мушмовъ } \\
/\end{array}$ & $198-217$ & $\begin{array}{c}5344 \\
\mathrm{NP}\end{array}$ \\
\hline
\end{tabular}

MINT OF DEULTUM

GORDIAN III

\begin{tabular}{|c|c|c|c|c|c|c|c|}
\hline \multicolumn{8}{|c|}{$\mathbf{A E}$} \\
\hline Cat. & Obverse & Reverse & $\begin{array}{l}\text { Wt. } \\
\text { Size } \\
\text { Axis }\end{array}$ & $\begin{array}{l}\text { Position } \\
\text { of find. }\end{array}$ & Ref. & Date & Vim. Coll. \\
\hline 9 & $\begin{array}{c}\text { IMP } \\
\text { GORDIANVS } \\
{[\ldots]} \\
\text { Bust dr. cuir. r., } \\
\text { head rad. }\end{array}$ & $\begin{array}{l}\text { COL FL PAC - } \\
\text { DEVLT } \\
\text { Athena helm. } \\
\text { stg. 1., hld. spear, } \\
\text { resting r. hand on } \\
\text { shield. }\end{array}$ & $\begin{array}{c}5,70 \\
23,03 \\
\mathrm{~S}\end{array}$ & $G-4200$ & $\begin{array}{c}\text { Similar } \\
\text { Мушмовъ } \\
\text { 3673-3674. }\end{array}$ & $238-244$ & $\begin{array}{c}11309 \\
\text { NP }\end{array}$ \\
\hline
\end{tabular}

MINT OF BYZANTIUM

AE - Unknown ruller

\begin{tabular}{|c|c|c|c|c|c|c|}
\hline Cat. & Obverse & Reverse & $\begin{array}{c}\text { Wt. } \\
\text { Size } \\
\text { Axis }\end{array}$ & $\begin{array}{c}\text { Position of } \\
\text { find. }\end{array}$ & Date & Vim. Coll. \\
\hline \multirow{2}{*}{10} & $\begin{array}{c}\text { Illegible. } \\
\text { Bust r. }\end{array}$ & $\begin{array}{c}\text { BVZAN-TI } \Omega \mathrm{N} \\
\text { Bunch of grapes } \\
\text { on a stem. }\end{array}$ & $\begin{array}{c}5,07 \\
22,48 \\
\mathrm{~N}\end{array}$ & Trench 444 & $\begin{array}{c}\text { Caracalla } \\
(?)\end{array}$ & 13437 \\
\hline
\end{tabular}




\section{MINT OF HADRIANOPOLIS \\ CARACALLA}

AE

\begin{tabular}{|c|c|c|c|c|c|c|c|}
\hline Cat. & Obverse & Reverse & $\begin{array}{l}\text { Wt. } \\
\text { Size } \\
\text { Axis }\end{array}$ & $\begin{array}{l}\text { Position } \\
\text { of find. }\end{array}$ & Ref. & Date & Vim. Coll. \\
\hline 11 & $\begin{array}{c}\text { AVT K M ANT } \\
\text { ANT } \Omega N E I N O C \\
\text { AV } \Gamma \\
\text { Bust dr. cuir. r., } \\
\text { head laur. }\end{array}$ & $\begin{array}{l}\text { A } \triangle \mathrm{PIANO}-\Pi- \\
\mathrm{O} \Lambda \mathrm{EIT} \Omega \mathrm{N}(\Omega \mathrm{N} \\
\text { in ligat.) } \\
\text { Tyche stg. 1., } \\
\text { hld. rudder and } \\
\text { cornucopiae. }\end{array}$ & $\begin{array}{c}7,79 \\
26,93 \\
S\end{array}$ & $G-1967$ & $\begin{array}{l}\text { Вьрбанов } \\
\text { III, } 3599 .\end{array}$ & $198-217$ & $\begin{array}{c}5483 \\
\mathrm{NP}\end{array}$ \\
\hline 12 & $\begin{array}{c}\text { AVT K M AVP } \\
{[\ldots]} \\
\text { Bust r., head laur. }\end{array}$ & $\begin{array}{c}{[\ldots] \text { AIANO - }} \\
\text { ПO } \Lambda[\ldots] \\
\text { Hera stg. } 1 ., \\
\text { holding sceptre } \\
\text { in 1. hand and in } \\
\text { r. hand a patera } \\
\text { over open cista } \\
\text { from which a } \\
\text { serpent is rising. }\end{array}$ & $\begin{array}{c}18,20 \\
29,95 \\
\mathrm{~N}\end{array}$ & $\begin{array}{c}\text { Trench } \\
309\end{array}$ & $\begin{array}{c}\text { Мушмовъ } \\
2651 .\end{array}$ & $198-217$ & $5313 / 3$ \\
\hline
\end{tabular}

GORDIAN III

\begin{tabular}{|c|c|c|c|c|c|c|c|}
\hline Cat. & Obverse & Reverse & $\begin{array}{l}\text { Wt. } \\
\text { Size } \\
\text { Axis }\end{array}$ & $\begin{array}{l}\text { Position } \\
\text { of find. }\end{array}$ & Ref. & Date & Vim. Coll. \\
\hline 13 & $\begin{array}{c}\text { AVT K M ANT } \\
-[\ldots] \\
\text { Bust dr. cuir. r., } \\
\text { head laur. }\end{array}$ & $\begin{array}{l}\text { A } \triangle \text { PIANOП-O-[...] } \\
\text { Artemis adv. 1., hld. } \\
\text { with boath hands } \\
\text { long torch. }\end{array}$ & $\begin{array}{c}10,56 \\
27,97 \\
\mathrm{~N}\end{array}$ & $\begin{array}{l}\text { G1 - } \\
1004\end{array}$ & $\begin{array}{c}\text { Мушмовъ } \\
2704 .\end{array}$ & $238-244$ & 11057 \\
\hline
\end{tabular}

MINT OF PHILIPPOPOLIS

ANTONINUS PIUS

\begin{tabular}{|c|c|c|c|c|c|c|c|}
\hline \multicolumn{8}{|c|}{$\mathbf{A E}$} \\
\hline Cat. & Obverse & Reverse & $\begin{array}{l}\text { Wt. } \\
\text { Size } \\
\text { Axis }\end{array}$ & $\begin{array}{l}\text { Position } \\
\text { of find. }\end{array}$ & Ref. & Date & Vim. Coll. \\
\hline 14 & $\begin{array}{c}\text { AVT AI A } \triangle \text { PIA - } \\
\text { ANT } \Omega N E I N O C \\
\text { Head laur. r. }\end{array}$ & 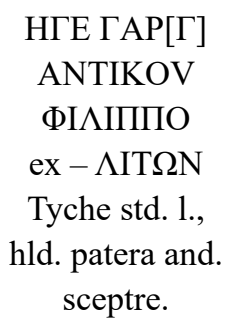 & $\begin{array}{c}17,46 \\
32,02 \\
\mathrm{~N}\end{array}$ & $\begin{array}{c}\text { Trench } \\
340\end{array}$ & $\begin{array}{c}\text { Мушмовъ } \\
5102 .\end{array}$ & $138-161$ & $\begin{array}{c}8867 \\
\mathrm{NP}\end{array}$ \\
\hline
\end{tabular}




\begin{tabular}{|c|c|c|c|c|c|c|c|}
\hline Cat. & Obverse & Reverse & $\begin{array}{l}\text { Wt. } \\
\text { Size } \\
\text { Axis }\end{array}$ & $\begin{array}{l}\text { Position } \\
\text { of find. }\end{array}$ & Ref. & Date & Vim. Coll. \\
\hline 15 & $\begin{array}{c}\text { Illegible } \\
\text { Head laur. r. }\end{array}$ & $\begin{array}{c}\text { ФІ ІІППО- } \\
\text { ПО } \Lambda \text { ЕТ } \Omega \mathrm{N} \\
\text { Homonoia stg. 1., } \\
\text { hld. patera and } \\
\text { cornucopiae. }\end{array}$ & $\begin{array}{c}3,56 \\
18,39 \\
\mathrm{~S}\end{array}$ & $\begin{array}{c}\text { Trench } \\
380\end{array}$ & $\begin{array}{c}\text { Мушмовъ } \\
5112 .\end{array}$ & $138-161$ & $\begin{array}{c}11713 \\
\text { NP }\end{array}$ \\
\hline
\end{tabular}

MINT OF PERINTHOS

CARACALLA

AE MEDALLION

\begin{tabular}{|c|c|c|c|c|c|c|c|}
\hline Cat. & Obverse & Reverse & $\begin{array}{l}\text { Wt. } \\
\text { Size } \\
\text { Axis }\end{array}$ & $\begin{array}{l}\text { Position } \\
\text { of find. }\end{array}$ & Ref. & Date & Vim. Coll \\
\hline 16 & 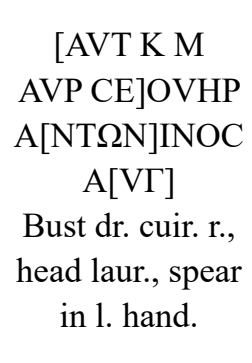 & $\begin{array}{c}{[\Pi E] \mathrm{P}[\mathrm{IN} \Theta \mathrm{I} \Omega] \mathrm{N}} \\
{[\mathrm{NE}] \Omega \mathrm{KOP}} \\
\text { ex - } \Omega \mathrm{N} \\
\text { Caracalla in slow } \\
\text { quadriga on } 1 . ; \\
\text { hld. eagle-tipped } \\
\text { sceptre. }\end{array}$ & $\begin{array}{c}43,88 \\
40,06 \\
\text { S }\end{array}$ & $G-4215$ & $\begin{array}{c}\text { obv. like } \\
\text { Мушмовъ } \\
4547 ; \\
\text { rev. like } \\
\text { Мушмовъ } \\
\text { 4549; ВМС } \\
\text { Thrace } 153 \text {, } \\
\text { no. } 40 .\end{array}$ & $211-217$ & 11326 \\
\hline
\end{tabular}

SEVERUS ALEXANDER

AE

\begin{tabular}{|c|c|c|c|c|c|c|c|}
\hline Cat. & Obverse & Reverse & $\begin{array}{l}\text { Wt. } \\
\text { Size } \\
\text { Axis }\end{array}$ & $\begin{array}{l}\text { Position } \\
\text { of find. }\end{array}$ & Ref. & Date & Vim. Coll. \\
\hline 17 & $\begin{array}{c}\text { AV K M } \\
\text { AVP CEV - } \\
\text { A } \Lambda \text { E } \Xi \mathrm{AN} \Delta \mathrm{POS} \\
\text { AV (AV in ligat.) } \\
\text { Bust dr. cuir. r., } \\
\text { head laur. }\end{array}$ & $\begin{array}{l}\text { ПEPIIN@IWN } \\
\text { IWN (WN } \\
\text { in ligat.) - B } \\
\text { NEWKOPWN } \\
\text { Asklepios stg. 1., } \\
\text { hld. serpent-en- } \\
\text { twined staff. }\end{array}$ & $\begin{array}{c}9,40 \\
30,96 \\
S\end{array}$ & $G-4215$ & $\begin{array}{c}\text { Мушмовъ } \\
4626 .\end{array}$ & $222-235$ & 11321 \\
\hline
\end{tabular}




\section{MOESIA INFERIOR}

MINT OF NICOPOLIS AD ISTRUM

CARACALLA

AE

\begin{tabular}{|c|c|c|c|c|c|c|c|}
\hline Cat. & Obverse & Reverse & $\begin{array}{l}\text { Wt. } \\
\text { Size } \\
\text { Axis }\end{array}$ & $\begin{array}{l}\text { Position } \\
\text { of find. }\end{array}$ & Ref. & Date & Vim. Coll. \\
\hline 18 & $\begin{array}{c}\text { AV } \bullet \mathrm{K} \bullet \\
\mathrm{M} \bullet \mathrm{AVP}- \\
\mathrm{ANT} \Omega \mathrm{NIN} \\
\text { Bust dr. cuir. r., } \\
\text { head laur. }\end{array}$ & 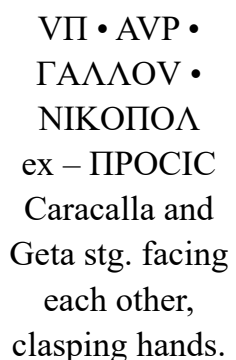 & $\begin{array}{c}12,03 \\
26,93 \\
\mathrm{~N}\end{array}$ & $G-4215$ & $\begin{array}{c}\text { Мушмовъ } \\
\text { 1101, but } \\
\text { diferent rev. } \\
\text { leg. }\end{array}$ & $198-217$ & $11327 / 1$ \\
\hline
\end{tabular}

ELAGABALUS

AE

\begin{tabular}{|c|c|c|c|c|c|c|c|}
\hline Cat. & Obverse & Reverse & $\begin{array}{l}\text { Wt. } \\
\text { Size } \\
\text { Axis }\end{array}$ & $\begin{array}{l}\text { Position } \\
\text { of find. }\end{array}$ & Ref. & Date & Vim. Coll. \\
\hline 19 & $\begin{array}{c}\text { [AVT K } \\
\text { M AVRH] } \\
\text {-ANTSNEINOC } \\
\text { Bust dr. r., head } \\
\text { laur. }\end{array}$ & 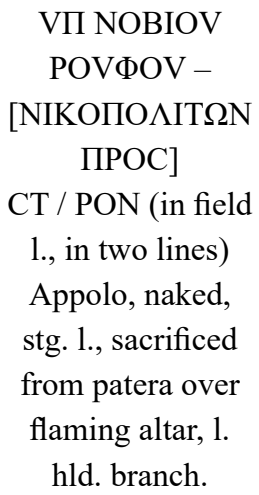 & $\begin{array}{c}10,84 \\
26,51 \\
\mathrm{~S}\end{array}$ & $G-2055$ & $\begin{array}{c}\text { like } \\
\text { Мушмовъ } \\
1371 \text { and } \\
1374 .\end{array}$ & $218-222$ & $\begin{array}{c}5681 \\
\text { NP }\end{array}$ \\
\hline
\end{tabular}



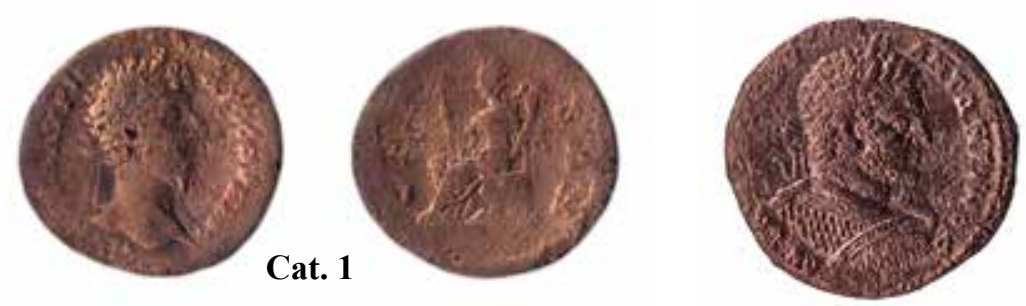

Cat. 2
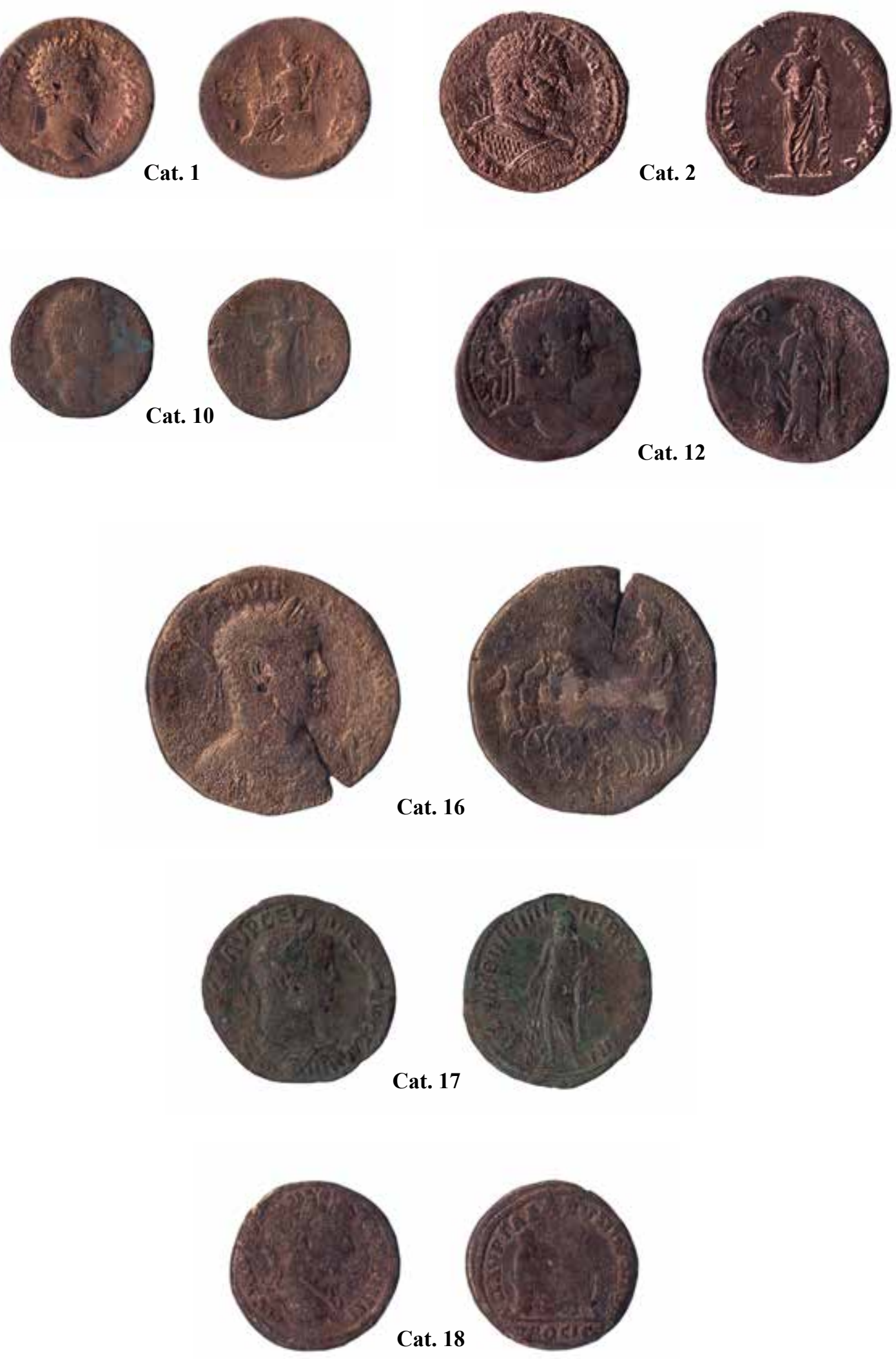


\section{$* * *$}

Arheologija i prirodne nauke (Archaeology and Science) is an Open Access Journal. All articles can be downloaded free of charge and used in accordance with the licence Creative Commons - Attribution-NonCommercial-NoDerivs 3.0 Serbia (https://creativecommons.org/licenses/bync-nd/3.0/rs/.

Časopis Arheologija i prirodne nauke je dostupan u režimu otvorenog pristupa. Članci objavljeni u časopisu mogu se besplatno preuzeti sa sajta i koristiti u skladu sa licencom Creative Commons - Autorstvo-Nekomercijalno-Bez prerada 3.0 Srbija (https://creativecommons.org/licenses/bync-nd/3.0/rs/.

\section{BIBLIOGRAPHY}

BMC Thrace, B. Head and P. Gardner, 1963 A Catalogue of Greek Coins in the British Museum. Catalogue of Greek Coins. The Tauric Chersonese, Sarmatia, Dacia, Moesia, Thrace, London (reprint): British Museum Trustees.

\section{Borić-Brešković B., Vojvoda M. 2017}

Coins of the Stobi Colony from the necropolises of Viminacium - Više Grobalja and Pećine, $\mathrm{Nu}$ mizmatičar 35: 7-31.

\section{Црнобрња Н., 1981}

Новач града Никеје у нумизматичкој збиричи Музеја града Београда, Годишњак града Београда 28: 5-23.

(Crnobrnja N., 1981

Novac grada Nikeje u numizmatičkoj zbirci Muzeja grada Beograda, Godišnjak grada Beograda 28: 5-23.)

\section{Kos P., Šemrov A. 1996 \\ Sylloge Nummorum Graecorum Slovenia III. Moesia Superior. Collection Kecskés 1. Viminaci- um (nos. 1-2381), Milano: Ennerre.}

\section{Mathiesen H, E. (ed.) 1986}

Sylloge Nummorum Graecorum. Aarhus University, Denmark, Copenhagen 1986: Munksgaard.

\section{Мушмовъ Н. А. 1912}

Антични монети на Балкански полуостров, София: Печатница на Г.И. Гавазов.

(Mušmov" N. A. 1912

Antični moneti na Balkanski poluostrov, Sofiia:

Pečatnica na G.I. Gavazov.)

\section{Nicolet H. 1983}

Sylloge Nummorum Graecorum, France. Bibliothèque Nationale. Cabinet des Médailles. Collection Jean et Marie Delepierre, Paris: Bibliothèque Nationale.

\section{RPC online,}

http://rpc.ashmus.ox.ac.uk/coins (15.1.2018).

\section{Varbanov I. 2007}

Greek Imperial Coins. Vol. III. Thrace. Chersonesos Thraceiae, Insula Thraciae, Macedonia, Bourgas: Adicom.

\section{Vojvoda M. 2011}

Coins from mints of Thrace and Lower Moesia on the Viminacium cemetery Više Grobalja, Arheologija i prirodne nauke 6: 139-152.

\section{Vojvoda M., 2017}

Coins of the Bithynian Mint of Nicaea from the Viminacium Necropolis of Pećine, Starinar LXVII, 131-150.

\section{Војвода М., Бранковић Т. 2016}

Новац битинијске ковнице Никеје из римске нумизматичке збирке народног музеја у Пожаревцу, Нумизматичар 34: 103-142.

(Vojvoda M., Branković T. 2016

Novac bitinijske kovnice Nikeje iz rimske numizmatičke zbirke narodnog muzeja u Požarevcu, Numizmatičar 34: 103-142.) 


\section{Војвода М., Јесретић М. 2012}

Новац битинијске ковнице Никеје из Музеја Срема у Сремској Митровици, Нумизматичар 30: 115-132.

(Vojvoda M., Jesretić M. 2012

Novac bitinijske kovnice Nikeje iz Muzeja Srema u Sremskoj Mitrovici, Numizmatičar 30: 115132.)

\section{Vojvoda M., Mrđić N. 2015}

Coin finds from the Viminacium necropolis of Više grobalja and their role in funerary ritual/Nalazi novca sa viminacijumske nekropole Više grobalja i njihova uloga u pogrebnom ritualu, Beograd: Institute of Archaeology.

\section{Vojvoda M., Mrđić N. 2017}

Coin finds from the Viminacium necropolis of Pecine and their role in funerary ritual/Nalazi novca sa viminacijumske nekropole Pećine i njihova uloga u pogrebnom ritualu, Beograd: Institute of Archaeology.

\section{Војвода М., Петровић С. 2011}

Новац битинијске ковнице Никеје из Бановог Поља у Мачви, Нумизматичар 29, 283-307.

(Vojvoda M., Petrović S. 2011

Novac bitinijske kovnice Nikeje iz Banovog Polja u Mačvi, Numizmatičar 29, 283-307.)

\section{von Aulock H., Kleiner G. 1957}

Sylloge Nummorum Graecorum, Deutschland, Sammlung Hans Von Aulock. Vol. 1: Pontus, Paphlagonia, Bithynia, Mysia, Troas, Aiolis, Lesbos, Ionia. Berlin: Mann.

\section{Зотовић Љ. 1986}

Јужне некрополе Виминација и погребни обреди, VIMINACIVM 1, Зборник радова Народног музеја у Пожаревцу: 41-60.

(Zotović LJ. 1986

Južne nekropole Viminacija i pogrebni obredi, VIMINACIVM 1, Zbornik radova Narodnog muzeja u Požarevcu: 41-60.)

\section{Зотовић Љ., Јордовић Ч. 1990}

VIMINACIVM I, Некропола »Више гробаља«, Београд: Археолошки институт, Републички завод за заштиту споменика културе Београд. (Zotović LJ., Jordović Č. 1990

VIMINACIVM I, Nekropola »Više grobalja«, Beograd: Arheološki institut, Republički zavod za zaštitu spomenika kulture Beograd.)

Waddington W.H., Babelon E., Reinach Th. 1910 Recueil général des Monnaies grècques d'Asie Mineure, Nicée et Nicomédie, Paris.

REZIME

NOVAC TRAČKIH I

DONJOMEZIJSKIH KOVNICA SA VIMINACIJUMSKE NEKROPOLE PEĆINE

\section{KLJUČNE REČI: RIMSKO PROVINCIJALNO KOVANJE, TRAKIJA, MEZIJA INFERIOR, VI- MINACIJUM, PEĆINE, VIŠE GROBALJA.}

Tokom obimnih zaštitnih arheoloških istraživanja južnih nekropola Viminacijuma, na nekropolama lokaliteta Pećine otkriveno je ukupno 3865 primeraka novca. Od 545 primeraka sa nekropole Pećine identifikovanih kao provincijalno kovanje, registrovano je ukupno 19 primeraka $(3,50 \%)$ koji su emitovani u kovnicama Trakije (17) i Donje Mezije (2) (Tabela 1). Što predstavlja nešto manji procenat $u$ odnosu na susednu nekropolu Više Grobalja, gde je registrovano 25 primeraka, što iznosi $4,50 \%$ od ukupnog broja registrovanih novčića provincijalnih kovnica. Uočljiva je i razlika u zastupljenosti kovnica dve provincije na nekropolama Više Grobalja i Pećine. Na nekropoli Više Grobalja su nalazi novca kovnica Donje Mezije

Uporednom analizom nalaza novca tračkih i donjomezijskih kovnica na obe viminacijumske nekropole, zapažaju se podudarnosti u više aspekata: zastupljenost vladara i članova porodi- 
ca kreće se u približnom hronološkom rasponu: Hadrianus (Pećine)/Antonin Pije (Više Grobalja) - Gordian III (Pećine)/Philip I (Više Grobalja) (Tabela 2); u najvećem procentu prisutan je novac Karakale (Pećine 36.84\%; Više Grobalja 20\%) i konačno najzastupljenije su emisije kovnice Pautalija (Tabela 1). daleko bolje zastupljeni u odnosu nekropolu Pećine (Grafikon 1a, b). Nalazi tračkih i donjomezijskih kovnica koji potiču sa grobljanskih areala lokaliteta Više Grobalja i Pećine kreću se u rasponu od Hadrijana do Filipa I sa ukupno 44 primeraka (Tabela 3).

Tračke i donjomezijske kovnice očito su imale izvesnog udela u snabdevanju Gornje Mezije sitnim bronzanim novcem do vladavine Karakale zajedno sa makedonskim kovnicama koje su ipak prednjačile. Izvanredna pojava novca bitinijske kovnice Nikeje tokom vladavine Aleksandra Severa u cirkulaciji Gornje Mezije, svakako je povezana sa ranijim snabdevanjem iz kovnice Stobi i potonjim viminacijumskim provincijskim kovanjem. Monetarni nalazi sa Viminacijuma, svojim velikim uzorkom kao i sigurnim mestom nalaza, u najvećoj meri doprinose razrešavanju pitanja granica cirkulacije provincijskog novca u ovom delu Carstva. 